\title{
La nueva regulación de los convenios: la conversión en derecho positivo de una práctica administrativa*
}

\author{
$M^{a}$ del Pilar Bensusan Martín \\ Acreditada como Catedrática de Universidad \\ Profesora Titular de Derecho Administrativo \\ Universidad de Granada
}

\begin{abstract}
SUMARIO: I.- INTRODUCGIÓN. II.- CONGEPTO Y NATURALEZA JURÍDICA DE LOS CONVENIOS. III.- CLASES DE CONVENIOS. IV.- REQUISITOS DE VALIDEZ Y EFICACIA DE LOS CONVENIOS. V. CONTENIDO DE LOS CONVENIOS. ESPECIAL REFERENCIA AL CONTENIDO DE LOS CONVENIOS INTERADMINISTRATIVOS. VI.- SUSCRIPCIÓN DE LOS CONVENIOS Y SUS EFECTOS. VII.- EXTINGIÓN Y RESOLUGIÓN DE LOS CONVENIOS. VIII.EFECTOS DE LA RESOLUGIÓN: LA LIQUIDACIÓN DE LOS CONVENIOS. IX. REMISIÓN DE LOS GONVENIOS AL TRIBUNAL DE GUENTAS. X.- ADAPTACIÓN DE LOS CONVENIOS VIGENTES. XI.- DISTINCIÓN ENTRE GONVENIOS, CONTRATOS Y SUBVENCIONES. 1. Diferencias entre convenios y contratos. 2. Diferencias entre convenios y subvenciones. 3. Diferencias entre contratos y subvenciones. XII.- GONGLUSIONES. XIII.- BIBLIOGRAFÍA.
\end{abstract}

RESUMEN: El presente estudio versa sobre la regulación que de los convenios administrativos hace la nueva Ley 40/2015, de 1 de octubre, de Régimen Jurídico del Sector Público, que positiviza este instrumento jurídico por vez primera de una manera plena en nuestro Derecho Administrativo en la línea prevista por la Moción 878/2010, de 30 de noviembre, del Tribunal de Cuentas a las Cortes Generales, sobre la necesidad de establecer un adecuado marco legal para el empleo del convenio de colaboración por las Administraciones Públicas. Tras más de veinte años de sequía en

* Este estudio se enmarca dentro del Proyecto I+D+I «Remodelando el empleo público y la organización administrativa para garantizar el Estado del Bienestar» (DER2013-48416- C2-1-R). 
la materia por la deficiente y escasa regulación que de los convenios se hacía en la Ley 30/1992, de 26 de noviembre, de Régimen Jurídico de las Administraciones Públicas y del Procedimiento Administrativo Común, la nueva norma desarrolla un régimen jurídico completo de los mismos, estableciendo una definición y unos tipos de convenios, unos requisitos para su validez y eficacia, delimitando su contenido, regulando los trámites preceptivos para su suscripción y sus efectos, determinando sus causas de extinción y los efectos de su resolución, así como su remisión al Tribunal de Cuentas. Se trata de una regulación parcialmente satisfactoria, toda vez que, una vez decidido el legislador a abordar el vacío legal existente, entre otros motivos, para evitar la utilización del instrumento convencional para huir de los rígidos controles de la legislación de contratos, o de la legislación de subvenciones, debería de haber hilado más fino, máxime tratándose de una norma eminentemente técnica. Esta juridificación de los convenios se analiza aquí desde un punto de vista crítico, pero desde la crítica constructiva, planteando asimismo la distinción entre convenios, contratos y subvenciones, precisamente para intentar evitar utilizaciones impropias de un instrumento como el convencional, cuyo uso se ha ido incrementando con el paso del tiempo a pesar de su fragilidad jurídica.

PALABRAS CLAVE: Convenio, convenios interadministrativos, convenios entre la Administración Pública y sujetos de Derecho privado, Ley de Régimen Jurídico del Sector Público, Tribunal de Cuentas, contrato, subvención, Ley del Procedimiento Administrativo Común de las Administraciones Públicas, Ley de Régimen Jurídico de las Administraciones Públicas y del Procedimiento Administrativo Común.

ABSTRACT: This study deals with the regulation of administrative agreements which does the new Law 40/2015, of 1 October, of the Legal Regime of the Public Sector, which positivizes this legal instrument for the first time in a fully way in our Administrative Law line provided by the Motion 878/2010 of 30 November, the Court of Auditors to Parliament on the need to establish an adequate legal framework for the use of the cooperation agreement by the Public Administrations. After more than twenty years of drought in the art from the poor and weak regulation of the agreements made in Law 30/1992 of 26 November on the Legal Regime of Public Administrations and Common Administrative Procedure, the new standard develops a comprehensive legal regime thereof, establishing a definition and types of agreements, some requirements for their validity and effectiveness, defining their content, regulating the mandatory procedures for subscription and its effects, determining the causes of extinction and the effects of its resolution and referral to the Court of Auditors. This is a partially satisfactory regulation, since, once the legislature to address the existing legal vacuum, among other reasons, decided to avoid the use of conventional instrument to escape the rigid controls of contract law, or subsidy legislation, there should be spun finer, especially in the case of an eminently technical standard. This 
juridification of the agreements analyzed here from a critical point of view, but from constructive criticism, also raising the distinction between agreements, contracts and grants, precisely to try to prevent improper uses of an instrument as conventional, whose use has been increasing over time despite its legal fragility.

KEY WORDS: Agreement, inter-administrative agreements, agreements between public administration and private actors Law, Legal Regime of the Public Sector, Court of Auditors, contract, grant, Law Common Administrative Procedure Public Administration, Law on the Legal Regime of Public Administrations and Common Administrative Procedure.

\section{INTRODUCGIÓN}

"Atrévete a pensar" Immanuel Kant

Cuando se aborda desde el punto de vista teórico el estudio de cualquier idea, concepto o institución se tiende a dar por bueno lo escrito, máxime si se trata de textos legales, por eso me complace que Kant titulase sus grandes obras con la palabra "Crítica", ${ }_{1}$ porque ese es el enfoque con el que hay que analizar siempre todo lo que nos rodea. Y este es, por tanto, el espíritu con el que voy a estudiar aquí la nueva regulación que de los convenios hace la Ley 40/2015, de 1 de octubre, de Régimen Jurídico del Sector Público².

Recogidos en un capítulo propio, el VI, del Título Preliminar de esta nueva norma, los convenios administrativos se positivizan por vez primera de una manera plena en nuestro Derecho Administrativo en la línea prevista en la Moción 878 del Tribunal de Cuentas, de 30 de noviembre de $2010^{3}$, que recomendaba sistematizar su marco legal y tipología, establecer los requisitos para su validez, e imponer la obligación de

\footnotetext{
(1790).

KANT, Immanuel, Crítica de la razón pura (1781), Crítica de la razón práctica (1788) y Crítica del juicio

Boletín Oficial del Estado n ${ }^{\circ}$ 236, de 2 de octubre de 2015, que entró en vigor el 2 de octubre de 2016

3 Moción 878/2010, de 30 de noviembre, del Tribunal de Cuentas a las Cortes Generales, sobre la necesidad de establecer un adecuado marco legal para el empleo del convenio de colaboración por las Administraciones Públicas.
} 
remitirlos al propio Tribunal de Cuentas ${ }^{4}$. De este modo, se desarrolla un régimen jurídico completo -o incompleto, ya se verá- de los convenios, fijando su contenido mínimo, clases, duración y extinción, y asegurando su control por el Tribunal de Cuentas, distanciándose de la deficiente y escasa regulación anterior ${ }^{5}$ que de ellos se hacía en la Ley

4 Las dieciséis propuestas que hizo el Tribunal de Cuentas para su consideración por las Cortes Generales y su traslado al Gobierno u otras instancias fueron, resumidamente, las siguientes: $1^{\circ}$.Que se complete y sistematice el marco legal vigente respecto de los convenios de colaboración, formulando un concepto que los diferencie de figuras afines, precisando sus ámbitos subjetivo y objetivo y los extremos de su contenido. $2^{\circ}$.- Que se precise el régimen aplicable a los convenios celebrados por entidades públicas que se rigen por el derecho privado con otras entidades o Administraciones Públicas (el de los convenios interadministrativos o el de los convenios con administrados). $3^{\circ}$.- Que se concrete si las relaciones entre Administraciones Públicas y organismos dependientes o vinculados deben canalizarse mediante convenios de colaboración o mediante encomiendas de gestión. $4^{\circ}$.- Que se adopten medidas eficaces para la efectiva aplicación de los principios de la legislación de contratos del sector público en los casos de ausencia de normas especiales. $5^{\circ}$.- Que en los convenios se delimiten con precisión el objeto y las actividades a realizar por las partes que convienen y la titularidad de los resultados. $6^{\circ}$.- Que en los convenios en los que haya que realizar aportaciones financieras, se fije con rigor en su importe, que nunca deberá rebasar el coste de la actividad a financiar ni su valor de mercado. $7^{\circ}$.- Que en las cláusulas de los convenios se incluyan las causas que pueden dar lugar a su modificación y resolución, así como las consecuencias del incumplimiento de sus compromisos. $8^{\circ}$.- Que se definan y clarifiquen los criterios de imputación presupuestaria del gasto. $9^{\circ}$.- Que se evite la contracción de compromisos de ejercicios futuros con cargo a créditos con asignación nominativa, ni aún condicionándolos a la futura concesión de otro crédito nominativo. $10^{\circ}$.- Que se evite la imputación automática de los saldos de compromisos no ejecutados del ejercicio anterior al presupuesto corriente sin una paralela modificación del plazo convenido. $11^{\circ}$.- Que se recabe la conformidad expresa de los suscriptores del convenio sobre las actuaciones a realizar cuando su concreción tenga que ser posterior a la suscripción del convenio. $12^{\circ}$.Que se atribuya a una comisión de seguimiento o a un responsable del convenio las facultades de supervisión del mismo. $13^{\circ}$.- Que se justifique la ejecución del convenio mediante la comprobación material de las inversiones realizadas, tanto por el órgano gestor como por la intervención. $14^{\circ}$.- En caso de que surjan dudas acerca de la delimitación de competencias entre el Estado y las Comunidades Autónomas, deberían de clarificarse en los convenios. $15^{\circ}$.- Que se complete y amplíe la información sobre los convenios mediante un sistema registral. 16 ${ }^{\circ}$.- Que se extienda a los convenios de colaboración la obligación de remitir información al Tribunal de Cuentas.

5 Para profundizar sobre ésta, vid. al respecto, ALMEIDA CERREDA, Marcos, "Un ordenamiento con lagunas normativas: El caso de los convenios administrativos", Observatorio de Contratación Pública, 19 de diciembre de 2011. 
30/1992, de 26 de noviembre, de Régimen Jurídico de las Administraciones Públicas y del Procedimiento Administrativo Común, concretamente en sus artículos 6 y 86 y $88^{7}$.

No obstante, habrá que analizar desde la crítica la novedosa juridificación de los convenios para concluir determinando cuáles sean sus auténticas bondades y sus deficiencias más palpables.

El origen del actual marco normativo se encuentra pues en el Boletín Oficial de las Cortes Generales número 480, de 28 de octubre de 2011, en el que se publicó la Relación de iniciativas, relativas a Comisiones Mixtas, que se trasladaron a las Cáma-

6 Boletín Oficial del Estado n ${ }^{\circ}$ 285, de 27 de noviembre de 1992, última actualización publicada el 2 de octubre de 2015. Su artículo 6 disponía así: "Convenios de colaboración. 1. La Administración General y los Organismos públicos vinculados o dependientes de la misma podrán celebrar convenios de colaboración con los órganos correspondientes de las Administraciones de las Comunidades Autónomas en el ámbito de sus respectivas competencias. 2. Los instrumentos de formalización de los convenios deberán especificar, cuando así proceda: a) Los órganos que celebran el convenio y la capacidad jurídica con la que actúa cada una de las partes. b) La competencia que ejerce cada Administración. c) Su financiación. d) Las actuaciones que se acuerden desarrollar para su cumplimiento. e) La necesidad o no de establecer una organización para su gestión.f) El plazo de vigencia, lo que no impedirá su prórroga si así lo acuerdan las partes firmantes del convenio. g) La extinción por causa distinta a la prevista en el apartado anterior, así como la forma de terminar las actuaciones en curso para el supuesto de extinción. 3. Cuando se cree un órgano mixto de vigilancia y control, éste resolverá los problemas de interpretación y cumplimiento que puedan plantearse respecto de los convenios de colaboración. 4. Cuando los convenios se limiten a establecer pautas de orientación política sobre la actuación de cada Administración en una cuestión de interés común o a fijar el marco general y la metodología para el desarrollo de la colaboración en un área de interrelación competencial o en un asunto de mutuo interés se denominarán Protocolos Generales. 5. Cuando la gestión del convenio haga necesario crear una organización común, ésta podrá adoptar la forma de consorcio dotado de personalidad jurídica o sociedad mercantil. Los estatutos del consorcio determinarán los fines del mismo, así como las particularidades del régimen orgánico, funcional y financiero. Los órganos de decisión estarán integrados por representantes de todas las entidades consorciadas, en la proporción que se fije en los Estatutos respectivos. Para la gestión de los servicios que se le encomienden podrán utilizarse cualquiera de las formas previstas en la legislación aplicable a las Administraciones consorciadas". Por su parte, el artículo 8 señala lo siguiente: "Efectos de los convenios. 1. Los convenios de Conferencia sectorial y los convenios de colaboración en ningún caso suponen la renuncia a las competencias propias de las Administraciones intervinientes. 2. Los convenios de Conferencia sectorial y los convenios de colaboración celebrados obligarán a las Administraciones intervinientes desde el momento de su firma, salvo que en ellos se establezca otra cosa. Tanto los convenios de Conferencia sectorial como los convenios de colaboración serán comunicados al Senado. Ambos tipos de convenios deberán publicarse en el «Boletín Oficial del Estado» y en el "Diario Oficial» de la Comunidad Autónoma respectiva. 3. Las cuestiones litigiosas que puedan surgir en su interpretación y cumplimiento, sin perjuicio de lo previsto en el artículo 6.3, serán de conocimiento y competencia del Orden Furisdiccional de lo Contencioso-Administrativo y, en su caso, de la competencia del Tribunal Constitucional".

7 Rezaba así el artículo 88 de la Ley 30/1992: "Terminación convencional. 1. Las Administraciones Públicas podrán celebrar acuerdos, pactos, convenios o contratos con personas tanto de derecho público como privado, siempre que no sean contrarios al Ordenamiento furídico ni versen sobre materias no susceptibles de transacción y tengan por objeto satisfacer el interés público que tienen encomendado, con el alcance, efectos y régimen jurídico específico que en cada caso prevea la disposición que lo regule, pudiendo tales actos tener la consideración de finalizadores de los procedimientos administrativos o insertarse en los mismos con carácter previo, vinculante o no, a la resolución que les ponga fin. 2. Los citados instrumentos deberán establecer como contenido mínimo la identificación de las partes intervinientes, el ámbito personal, funcional y territorial, y el plazo de vigencia, debiendo publicarse o no según su naturaleza y las personas a las que estuvieran destinados. 3. Requerirán en todo caso la aprobación expresa del Consejo de Ministros, los acuerdos que versen sobre materias de la competencia directa de dicho órgano. 4. Los acuerdos que se suscriban no supondrán alteración de las competencias atribuidas a los órganos administrativos ni de las responsabilidades que correspondan a las autoridades y funcionarios relativas al funcionamiento de los servicios públicos". 
ras que se constituyeron en la $\mathrm{X}$ Legislatura, entre las que se encontraba la ya mentada Moción 878/2010, de 30 de noviembre, del Tribunal de Cuentas a las Cortes Generales, sobre la necesidad de establecer un adecuado marco legal para el empleo del convenio de colaboración por las Administraciones Públicas.

Esta Moción fue una iniciativa crucial en este aspecto ya que comportó un antes y un después en la regulación de los convenios administrativos, fundamentalmente por el crecimiento que ha ido experimentando el recurso a este instrumento convencional desde principios de los años noventa hasta la actualidad por parte de las Administraciones Públicas, no sólo en sus relaciones con otras Administraciones Públicas, organismos públicos y entidades de Derecho público vinculados o dependientes o Universidades públicas, sino también en sus relaciones con sujetos de Derecho privado, con particulares. Y, a un tiempo, por el incremento del peso económico que los convenios han ido adquiriendo en las cuentas públicas de nuestras Administraciones, aún a pesar de la crisis económica, aunque evidentemente ésta ha ido provocando, como después se verá, un cambio en el contenido a la hora de suscribir determinados convenios. Junto a ello, una regulación en el ordenamiento jurídico-administrativo pésima, imprecisa, sin clara definición positiva, insuficiente, escasa y con un régimen jurídico incierto creaban las condiciones óptimas para dotarla un marco jurídico adecuado.

Dado que los artículos 47 a 53 de la Ley 40/2015, de 1 de octubre, de Régimen Jurídico del Sector Público disciplinan con detalle el régimen jurídico aplicable a los convenios, cualesquiera que sean las Administraciones Públicas que los celebren -estatal, autonómicas o locales-, en líneas siguientes se analizará si el objetivo se ha cumplido, si se ha dado respuesta a todas las propuestas del Tribunal de Cuentas y si esta regulación se plasmará adecuadamente en la práctica administrativa.

\section{CONCEPTO Y NATURALEZAJURÍDICA DE LOS CONVENIOS}

"Pensamientos sin contenidos son vacios; intuiciones sin conceptos son ciegas" Immanuel Kant

Nadie duda de la necesidad de delimitar un concepto legal, jurisprudencial o doctrinal de la institución del convenio, evidentemente para no seguir a ciegas, toda vez que la inexistencia de cualquiera de estos conceptos hasta ahora lo único que ha provocado es el empleo frecuente del término convenio para referirse a realidades jurídicas muy diversas, favoreciendo además la utilización de esta figura para ejecutar gasto público sin el encorsetamiento del Derecho Administrativo en materia de contratación pública y de fomento ${ }^{8}$. Lo único que ha precisado la doctrina en materia

8 DE DIEGO GÓMEZ, Alejandro, "La figura del convenio tras la Ley 40/2015, del Régimen Jurídico del Sector Público", El Consultor de los Ayuntamientos, no 23, quincena del 15 al 29 de diciembre de 2015, págs. 2757 a 2774. 
de convenios es que estamos ante un acuerdo de voluntades en un plano de igualdad en el que al menos una de las partes ha de ser necesariamente una Administración Pública ${ }^{9} \mathrm{y}$, en el caso de convenios interadministrativos, que se trata de técnicas que se basan en el pacto, en condiciones de igualdad, entre las Administraciones y Entes públicos con competencias sobre una materia ${ }^{10}$. Se trata pues, de acuerdos que van a suscribir las Administraciones Públicas entre sí, o con sujetos privados, para la realización de un fin común, mediante el que las partes deciden colaborar a efectos de conseguir alcanzar dicha finalidad. Y, en el caso de convenios interadministrativos, como recuerda el artículo 57.2 de la Ley 7/1985, de 2 de abril, Reguladora de las Bases del Régimen Local ${ }^{11}$, la suscripción de convenios deberá mejorar la eficiencia de la gestión pública, eliminar duplicidades administrativas y cumplir con la legislación de estabilidad presupuestaria y sostenibilidad financiera, cuestión reiterada ahora en su esencia para todo tipo de convenios por el artículo 48.3 de la Ley 40/2015, de 1 de octubre, de Régimen Jurídico del Sector Público.

Entendía en 2010 el Tribunal de Cuentas en lo relativo a la delimitación conceptual de los convenios, que las disposiciones contenidas en la derogada Ley 30/2007, de 30 de octubre, de Contratos del Sector Público ${ }^{12}$, hoy Real Decreto Legislativo 3/20011, de 14 de noviembre, por el que se aprueba el Texto Refundido de la Ley

9 DE DIEGO GÓMEZ, Alejandro, "La figura del convenio...", op. cit., págs. 2757 y 2758.

10 MARTÍN HUERTA, Pablo, Los convenios interadministrativos, Ministerio de Administraciones Públicas-INAP, 2000. Para mayor abundamiento sobre los convenios entre Administraciones Públicas, vid., VELASCO CABALLERO, Francisco, "Los convenios entre Administraciones Públicas", Revista Española de Derecho Administrativo, n 103, 1999, págs. 504 a 511, y RODRÍGUEZ DE SANTIAGO, José María, Los convenios entre Administraciones Públicas, Marcial Pons, Madrid, 1997, que, además de analizarlos minuciosamente conforme a la Ley 30/1992, estudia el recurso a este instrumento por la tradición existente en Alemania acerca de la celebración de convenios entre centros de poder público dotados de independencia, con especial referencia a las peculiaridades que revisten los convenios perfeccionados entre la Federación y los Estados federados. Para GONZÁLEZ-ANTÓN ÁLVAREZ, Carlos, Los convenios interadministrativos de los Entes Locales, Montecorvo, Madrid, 2002, págs. 22 y 23, "los convenios entre Administraciones son muy heterogéneos, por un lado, a pesar de ser entes públicos, la regulación puede ser similar a las relaciones Administración-administrados, y, por otro lado, están en los que existe una nota de equilibrio entre las partes del convenio, que son los denominados convenios de colaboración".

11 Boletín Oficial del Estado n ${ }^{\circ} 80$, de 3 de abril de 1985, última actualización publicada el 15 de julio de 2016. Artículo modificado por el artículo 1.16 de la Ley 27/2013, de 27 de diciembre, de racionalización y sostenibilidad de la Administración Local (Boletín Oficial del Estado no 312 , de 30 de diciembre de 2013, última actualización publicada el 15 de julio de 2016), norma cuyo artículo 1.17 añadió además el artículo 57 bis a la Ley 7/1985, de 2 de abril, Reguladora de las Bases del Régimen Local, relativo a la garantía de pago en el ejercicio de competencias delegadas, y que ha sido anulado tras ser declarado inconstitucional y nulo por Sentencia del Tribunal Constitucional 41 /2016, de 3 de marzo de 2016.

12 Boletín Oficial del Estado no 261, de 31 de octubre de 2007, última actualización publicada el 16 de noviembre de 2011." 
de Contratos del Sector Público ${ }^{13}$, a diferencia de lo que ocurría con el también derogado Real Decreto Legislativo 2/2000, de 16 de junio, por el que se aprobó el Texto Refundido de la Ley de Contratos de las Administraciones Públicas ${ }^{14}$, permitían delimitar un concepto sobre este instrumento jurídico. Señalaba a este respecto que "Con la nueva LCSP [...] resulta posible formular un concepto más preciso de convenio de colaboración, lo que constituye un importante avance en la configuración legal de la institución. Por ello, a partir de la legislación vigente, podría sostenerse que el convenio se caracteriza por la existencia de un acuerdo de voluntades productor de efectos jurídicos entre los sujetos que convienen, efectos que, por tanto, no proceden de uno solo de ellos sino de todos [...] En el convenio cada sujeto asume, junto al otro u otros con los que se formaliza el acuerdo de voluntades, una obligación de dar o de hacer, pero dicha obligación no tiene por causa "la prestación o promesa de una cosa o servicio por la otra parte", lo que lo situaría en el ámbito de los contratos onerosos (art. 1274 CC) sujetos a la LCSP (art. 2 LCSP). La causa de la aportación será la consecución de un fin común a los sujetos que convienen, y como quiera que, al menos uno de ellos, ha de ser una Administración pública, dicho fin habrá de ser de interés público ${ }^{\prime 15}$. Por ello, en sus propuestas el mentado Tribunal reiteraba la necesidad de formular un concepto de convenio que lo diferencie de figuras afines, precisando sus ámbitos subjetivo y objetivo y los extremos de su contenido ${ }^{16}$.

Y sí responde parcialmente la Ley 40/2015, de 1 de octubre, de Régimen Jurídico del Sector Público a las expectativas del Tribunal de Cuentas, aportando por vez primera un concepto jurídico de convenio, que recoge la idea del fin común, aunque no refiere expresamente que ese fin común ha de ser un fin de interés público. Sin embargo, no aporta su diferenciación conceptual con figuras jurídicas afines, para lo que habrá que hacer operaciones de encaje jurídico entre diversas normas. Reza así su artículo 47.1: "Son convenios los acuerdos con efectos jurídicos adoptados por las Administraciones Públicas, los organismos públicos y entidades de derecho público vinculados o dependientes o las Universidades públicas entre sí o con sujetos de derecho privado para un fin común". No obstante, el "fin común" aparece como un concepto jurídico indeterminado que puede ampliar o reducir el ámbito de potenciales acuerdos, lo cual puede dar lugar a confusiones o a una relativa inseguridad jurídica. Brilla, por tanto, por su ausencia una definición acerca de la concurrencia de la satisfacción de un fin común entre la Administración y los particulares, que, de existir, evitaría situaciones confusas, toda vez que, según

\footnotetext{
13 Boletín Oficial del Estado no 276, de 16 de noviembre de 2011, última actualización publicada el 31 de diciembre de 2015

14 Boletín Oficial del Estado n ${ }^{\circ}$ 148, de 21 de junio de 2000, última actualización publicada el 30 de abril de 2008.

15 Moción 878/2010, de 30 de noviembre, del Tribunal de Cuentas a las Cortes Generales, sobre la necesidad de establecer un adecuado marco legal para el empleo del convenio de colaboración por las Administraciones Públicas, págs. 2757 a 2774.

16 Propuesta $n^{\circ} 1^{\text {a }}$ de la Moción 878 del Tribunal de Cuentas, pág. 32.
} 
se interprete, el ámbito de posibles acuerdos puede ser más o menos amplio. Y brilla también por su ausencia un concepto de convenio que lo diferencie de figuras afines.

Por el contrario a esta definición positiva, la definición negativa de convenio se da en el párrafo siguiente al señalar que no tienen la consideración de convenios los Protocolos Generales de Actuación o instrumentos similares que comporten meras declaraciones de intención de contenido general o que expresen la voluntad de las Administraciones y partes suscriptoras para actuar con un objetivo común, siempre que no supongan la formalización de compromisos jurídicos concretos y exigibles. Además, los convenios no podrán tener por objeto prestaciones propias de los contratos. En tal caso, su naturaleza y régimen jurídico se ajustará a lo previsto en la legislación de contratos del sector público. Con ello, se sitúa a los convenios en una difícil posición intermedia ${ }^{17}$.

Se pasa pues de la nada conceptual a la indigestión de conceptos, con una definición en positivo y otra en negativo manifiestamente mejorables, a las que hay que añadir, para mayor complicación, lo preceptuado en el artículo 86 de la Ley 39/2015, de 1 de octubre, del Procedimiento Administrativo Común de las Administraciones Públicas ${ }^{18}$, aunque en ésta norma sí se viene a aportar la idea de que el instrumento convencional debe tener por objeto la satisfacción del interés público. No obstante, la dificultad se incrementa notablemente para el lector-operador jurídico al optarse ahora por la referencia conceptual genérica a "convenios", frente a la anterior regulación más específica que se refería a "convenios de colaboración”, aunque en todo convenio sub-

17 JIMÉNEZ-BLANCO CARRILLO DE ALBORNOZ, Antonio, "Organización administrativa y relaciones interadministrativas", Documentación Administrativa, n² 2, enero-diciembre 2015, pág. 4, que remarca esta difícil posición intermedia para los convenios que, teniendo efectos jurídicos, su objeto no son actos de contenido jurídico.

18 Boletín Oficial del Estado n ${ }^{\circ} 236$, de 2 de octubre de 2015, que entrará en vigor el 2 de octubre de 2016. Dice así el mentado artículo 86: "Terminación convencional. 1. Las Administraciones Públicas podrán celebrar acuerdos, pactos, convenios o contratos con personas tanto de Derecho público como privado, siempre que no sean contrarios al ordenamiento jurídico ni versen sobre materias no susceptibles de transacción y tengan por objeto satisfacer el interés público que tienen encomendado, con el alcance, efectos y régimen jurídico específico que, en su caso, prevea la disposición que lo regule, pudiendo tales actos tener la consideración de finalizadores de los procedimientos administrativos o insertarse en los mismos con carácter previo, vinculante o no, a la resolución que les ponga fin. 2. Los citados instrumentos deberán establecer como contenido mínimo la identificación de las partes intervinientes, el ámbito personal, funcional y territorial, y el plazo de vigencia, debiendo publicarse o no según su naturaleza y las personas a las que estuvieran destinados. 3. Requerirán en todo caso la aprobación expresa del Consejo de Ministros u órgano equivalente de las Comunidades Autónomas, los acuerdos que versen sobre materias de la competencia directa de dicho órgano. 4. Los acuerdos que se suscriban no supondrán alteración de las competencias atribuidas a los órganos administrativos, ni de las responsabilidades que correspondan a las autoridades y funcionarios, relativas al funcionamiento de los servicios públicos. 5. En los casos de procedimientos de responsabilidad patrimonial, el acuerdo alcanzado entre las partes deberá fijar la cuantía y modo de indemnización de acuerdo con los criterios que para calcularla y abonarla establece el artículo 34 de la Ley de Régimen Furídico del Sector Público". 
yazca el principio de colaboración. No obstante, creo positivo el paso de un concepto más concreto a otro más general a la hora de clarificar todo este embrollo.

Independientemente de lo anterior, destacan en este concepto jurídico de convenio las nociones de finalidad común -los intereses comuúnes entre las partes que convienen diferencian esta figura de los contratos o las subvenciones, como después se analizará-, aunque ya se ha apuntado su indeterminación; de interés público; de voluntariedad en la suscripción del convenio -que excluye cualquier tipo de procedimiento selectivo-; y el plano de igualdad -cuanto menos teórica- entre las partes que convienen, una de las cuales ha de ser necesariamente una Administración Pública en los términos descritos supra ${ }^{19}$.

Respecto a la naturaleza jurídica de los convenios, es evidente su naturaleza jurídico-pública toda vez que deben de celebrarse por, al menos, una Administración Pública, su finalidad debe ser exclusivamente de interés público y se someten íntegramente al Derecho Administrativo. Asimismo, las cuestiones litigiosas que se deriven tanto de su interpretación como de su cumplimiento deberán sustanciarse en la jurisdicción contencioso-administrativa. No obstante, esta no es cuestión pacífica para algún autor, en el entendimiento de que la nueva regulación no clarifica la naturaleza jurídica de los convenios con particulares, y "aunque pueda parecer una obviedad que se trata de convenios administrativos, lo cierto es que no se justifica que la Administración ostente las prerrogativas de modificación o interpretación unilateral, ni tampoco que las controversias sean competencia del orden contencioso-administrativo"20, y ello, aún a pesar de lo dispuesto en la Exposición de Motivos de la Ley, que se refiere a ellos como convenios administrativos, y, por supuesto, de lo dispuesto a este respecto en el artículo 29.1 de la Ley 29/1998, de 13 de julio, de la Jurisdicción Contencioso-Administrativa ${ }^{21}$.

19 Igualdad teórica, toda vez que en la práctica las Administraciones impondrán una serie de cláusulas usualmente inamovibles, que condicionarán la voluntariedad en la aceptación por la otra parte. Vid. al respecto, DE DIEGO GÓMEZ, Alejandro, "La figura del convenio...", op. cit., pág. 2758.

${ }_{20}$ MUÑOZ, M ${ }^{\text {a }}$ Luisa y COYLE, Charles, "La nueva regulación de los convenios entre Administraciones Públicas y particulares", Actualidad Furídica Aranzadi, nº 914, 17 de diciembre de 2015, pág. 14.

21 Artículo que recordemos que dispone que: "Cuando la Administración, en virtud de una disposición general que no precise de actos de aplicación o en virtud de un acto, contrato o convenio administrativo, esté obligada a realizar una prestación concreta en favor de una o varias personas determinadas, quienes tuvieran derecho a ella pueden reclamar de la Administración el cumplimiento de dicha obligación. Si en el plazo de tres meses desde la fecha de la reclamación, la Administración no hubiera dado cumplimiento a lo solicitado o no hubiera llegado a un acuerdo con los interesados, éstos pueden deducir recurso contencioso-administrativo contra la inactividad de la Administración”. 


\section{GLASES DE GONVENIOS}

"El derecho es el conjunto de condiciones que permiten a la libertad de cada uno acomodarse a la libertad de todos" Immanuel Kant

Y en ese afán del derecho por clasificar, ordenar y encasillar sus actuaciones jurídicas, enmarcamos la clasificación que de los convenios hace la Ley 40/2015, de 1 de octubre, de Régimen Jurídico del Sector Público, con evidente ánimo esclarecedor. Así, conforme a su artículo 47.2, los convenios que suscriban las Administraciones Públicas, los organismos públicos y las entidades de Derecho público vinculados o dependientes y las Universidades públicas, deberán corresponder a alguno de los siguientes tipos:

a) Convenios interadministrativos firmados entre dos o más Administraciones Públicas, o bien entre dos o más organismos públicos o entidades de Derecho público vinculados o dependientes de distintas Administraciones Públicas, y que podrán incluir la utilización de medios, servicios y recursos de otra Administración Pública, organismo público o entidad de Derecho público vinculado o dependiente, para el ejercicio de competencias propias o delegadas. Quedan excluidos los convenios interadministrativos suscritos entre dos o más Comunidades Autónomas para la gestión y prestación de servicios propios de las mismas, que se regirán en cuanto a sus supuestos, requisitos y términos por lo previsto en sus respectivos Estatutos de Autonomía.

b) Convenios intradministrativos firmados entre organismos públicos y entidades de Derecho público vinculados o dependientes de una misma Administración Pública.

c) Convenios firmados entre una Administración Pública u organismo o entidad de Derecho público y un sujeto de Derecho privado.

d) Convenios no constitutivos ni de Tratado internacional, ni de Acuerdo internacional administrativo, ni de Acuerdo internacional no normativo, firmados entre las Administraciones Públicas y los órganos, organismos públicos o entes de un sujeto de Derecho internacional, que estarán sometidos al ordenamiento jurídico interno que determinen las partes.

Nada que objetar pues, no parece una diferenciación dificultosa o complicada de entender, al contrario, y delimita correctamente los diferentes tipos de convenios en función de quienes los suscriban, partiendo, como ya se ha dicho, de que deben de celebrarse por, al menos, una Administración Pública, aunque puedan suscribirse por dos, o incluso más, Administraciones. 


\section{REQUISITOS DE VALIDEZ Y EFICACIA DE LOS CONVENIOS}

"Toda oposición contra el supremo poder legislativo..., es el delito supremo y más punible en una comunidad, porque destruye sus fundamentos"

Immanuel Kant

Sin embargo, manifiesto en este apartado una oposición evidente a la tarea del legislador, como ahora se comprenderá.

Los requisitos para la validez y eficacia de los convenios que pueden suscribir las Administraciones Públicas, sus organismos públicos y entidades de Derecho público vinculados o dependientes y las Universidades públicas, en el ámbito de sus respectivas competencias, con sujetos de Derecho público y privado, se plasman en el artículo 48 de la Ley 40/2015, de 1 de octubre, de Régimen Jurídico del Sector Público, partiendo de una prohibición genérica, la de ceder la titularidad de la competencia.

A esta prohibición genérica se añade otra prohibición específica contenida en el artículo 48.9, la de aplicar las normas sobre convenios contenidas en el Capítulo VI a las encomiendas de gestión ${ }^{22}$ y a los acuerdos de terminación convencional de los procedimientos administrativos, lo que sorprendentemente deja sin este marco legal específico a los convenios que tengan la consideración de finalizadores de los procedimientos, reduciendo su regulación a lo preceptuado en el artículo 86 de la Ley 39/2015, de 1 de octubre, del Procedimiento Administrativo Común de las Administraciones Públicas, que únicamente establece su contenido mínimo -identificación de las partes intervinientes, ámbito personal, funcional y territorial, y plazo de vigencia, y publicación o no según su naturaleza y las personas a las que estuvieran destinados- y la necesidad de aprobación expresa del Consejo de Ministros u órgano equivalente de las Comunidades Autónomas cuando se trate de acuerdos que versen sobre materias de la competencia directa de dicho órgano ${ }^{23}$. Es verdaderamente un error del legislador excluir de esta novedosa regulación de los convenios a la terminación convencional de los procedimientos administrativos, y no sólo un error, sino una auténtica contradicción con el espíritu de la Ley 40/2015, de 1 de octubre, de Régimen Jurídico del Sector Público, en su afán de positivizar el instrumento convencional, máxime cuando la exclusión se hace de manera expresa. Y contradicción también con el propio dic-

22 Las encomiendas de gestión se regulan en el artículo 11 de la Ley 40/2015, de 1 de octubre, de Régimen Jurídico del Sector Público de forma bastante similar a la del anterior artículo 15 de la Ley 30/1992, pero es absolutamente sorprendente que en el número 3.b) de dicho artículo se prevea que cuando la encomienda de gestión se realice entre órganos y Entidades de Derecho Público de distintas Administraciones se formalizará mediante firma del correspondiente convenio, y posteriormente en el artículo 48.9 se excluya esta posibilidad.

23 Artículo 86.2 y 3 de la Ley 39/2015, de 1 de octubre, del Procedimiento Administrativo Común de las Administraciones Públicas. 
tado del artículo 86.1 de la Ley 39/2015, de 1 de octubre, del Procedimiento Administrativo Común de las Administraciones Públicas, cuando se refiere a la posibilidad de que las Administraciones Públicas celebren convenios. Es como si el legislador de la Ley 40/2015 fuera distinto y diera la espalda al de la Ley 39/2015 en materia de convenios, o que sorprendentemente estuviésemos ante un legislador bipolar.

Los requisitos de validez y eficacia de los convenios se recogen pues en los números del 2 al 8 del mentado artículo 48 de la Ley 40/2015, de 1 de octubre, de Régimen Jurídico del Sector Público, y son los siguientes:

a) Los convenios se perfeccionan por la prestación del consentimiento de las partes.

b) La suscripción de convenios deberá mejorar la eficiencia de la gestión pública, facilitar la utilización conjunta de medios y servicios públicos, contribuir a la realización de actividades de utilidad pública y cumplir con la legislación de estabilidad presupuestaria y sostenibilidad financiera.

c) La gestión, justificación y resto de actuaciones relacionadas con los gastos derivados de los convenios que incluyan compromisos financieros para la Administración Pública o cualquiera de sus organismos públicos o entidades de Derecho público vinculados o dependientes que lo suscriban, así como con los fondos comprometidos en virtud de dichos convenios, se ajustarán a lo dispuesto en la legislación presupuestaria.

d) Los convenios que incluyan compromisos financieros deberán ser financieramente sostenibles, debiendo quienes los suscriban tener capacidad para financiar los asumidos durante la vigencia del convenio.

e) Las aportaciones financieras que se comprometan a realizar los firmantes no podrán ser superiores a los gastos derivados de la ejecución del convenio.

f) Cuando el convenio instrumente una subvención deberá cumplir con lo previsto en la Ley 38/2003, de 17 de noviembre, General de Subvenciones ${ }^{24}$ y en la normativa autonómica de desarrollo que, en su caso, resulte aplicable. Asimismo, cuando el convenio tenga por objeto la delegación de competencias en una Entidad Local, deberá cumplir con lo dispuesto en Ley 7/1985, de 2 de abril, Reguladora de las Bases del Régimen Local.

g) En el ámbito de la Administración General del Estado y sus organismos públicos y entidades de Derecho público vinculados o dependientes, podrán celebrar

24 Boletín Oficial del Estado $n^{\circ} 276$, de 18 de noviembre de 2003, última actualización publicada el 20 de mayo de 2016. 
convenios los titulares de los Departamentos Ministeriales y los Presidentes o Directores de las dichas entidades y organismos públicos. Los convenios suscritos por la Administración General del Estado o alguno de sus organismos públicos o entidades de Derecho público vinculados o dependientes resultarán eficaces una vez inscritos en el Registro Electrónico estatal de Órganos e Instrumentos de Cooperación del sector público estatal, y publicados en el Boletín Oficial del Estado. Previamente y con carácter facultativo, se podrán publicar en el Boletín Oficial de la Comunidad Autónoma o de la provincia, que corresponda a la otra Administración firmante.

Requisitos estos que, a diferencia de lo referido antes, resultan coherentes con la naturaleza del instrumento convencional y que comportan unos mínimos ineludibles a la hora de suscribir convenios y darles validez.

\section{GONTENIDO DE LOS GONVENIOS. ESPEGIAL REFERENGIA AL CONTENIDO DE LOS CONVENIOS INTERADMINISTRA- TIVOS}

"Todo nuestro conocimiento arranca del sentido, pasa al entendimiento y termina en la razón" Immanuel Kant

Tras la evidencia de falta de sentido común, y, por tanto, de razón, en el legislador apreciada supra, es de justicia reconocer la mejoría considerable del texto en lo que al contenido de los convenios se refiere. Se determina expresamente un contenido mínimo en el artículo 49 de la Ley 40/2015, de 1 de octubre, de Régimen Jurídico del Sector Público. Su contenido debe ser, cuando menos, el siguiente:

a) Sujetos que suscriben el convenio y la capacidad jurídica con que actúa cada una de las partes.

b) La competencia en la que se fundamenta la actuación de la Administración Pública, de los organismos públicos y las entidades de Derecho público vinculados o dependientes de ella o de las Universidades públicas.

c) Objeto del convenio y actuaciones a realizar por cada sujeto para su cumplimiento, indicando, en su caso, la titularidad de los resultados obtenidos.

d) Obligaciones y compromisos económicos asumidos por cada una de las partes, si los hubiera, indicando su distribución temporal por anualidades y su imputación concreta al presupuesto correspondiente de acuerdo con lo previsto en la legislación presupuestaria. 
e) Consecuencias aplicables en caso de incumplimiento de las obligaciones y compromisos asumidos por cada una de las partes y, en su caso, los criterios para determinar la posible indemnización por el incumplimiento.

f) Mecanismos de seguimiento, vigilancia y control de la ejecución del convenio y de los compromisos adquiridos por los firmantes. Este mecanismo resolverá los problemas de interpretación y cumplimiento que puedan plantearse respecto de los convenios.

g) El régimen de modificación del convenio. A falta de regulación expresa la modificación del contenido del convenio requerirá acuerdo unánime de los firmantes ${ }^{25}$.

h) Y el plazo de vigencia del convenio, teniendo en cuenta que las siguientes reglas:

1. ${ }^{\circ}$ La novedad de la introducción de una duración determinada en los convenios, que no podrá ser superior a cuatro años, salvo que normativamente se prevea un plazo superior ${ }^{26}$.

2. ${ }^{\circ}$ En cualquier momento antes de la finalización del plazo previsto en el apartado anterior, los firmantes del convenio podrán acordar unánimemente su prórroga por un periodo de hasta cuatro años adicionales o su extinción. Teniendo presente que esta prórroga podrá realizarse por una sola $\mathrm{vez}^{27}$.

Pero, cuál sea el objeto concreto de los convenios no se especifica en esta nueva norma de tintes genéricos, aunque, en el caso de convenios suscritos entre la Administración General del Estado y las Comunidades Autónomas, puedan abarcar cualquier materia, por ejemplo, agricultura, alimentación, medio ambiente, economía, empleo y Seguridad Social, defensa, sanidad, servicios sociales e igualdad, fomento, interior, industria, energía y turismo, hacienda, educación, cultura y deporte, asuntos exteriores, cooperación, justicia, etc. ${ }^{28}$

25 Redactado conforme a la corrección de errores publicada en el BOE $n^{\circ} 306$, de 23 de diciembre de 2015 .

26 Como, por ejemplo, en la legislación local, en la que el artículo 27 de la Ley 7/1985, de 2 de abril, Reguladora de las Bases de Régimen Local, prevé una duración no inferior a 5 años para los convenios que articulen delegaciones de competencias de las Comunidades Autónomas en favor de los Ayuntamientos.

27 En el caso de convenios suscritos por la Administración General del Estado o alguno de sus organismos públicos y entidades de Derecho público vinculados o dependientes, esta prórroga deberá ser comunicada al Registro Electrónico estatal de Órganos e Instrumentos de Cooperación al que se refiere la Disposición Adicional Séptima.

28 INFORME SOBRE LOS CONVENIOS DE COLABORACIÓN ESTADO-COMUNIDADES AUTÓNOMAS SUSCRITOS DURANTE 2013, Ministerio de Hacienda y Administraciones Públicas, 2013, pág. 7 y ss. 
Según el Informe sobre los Convenios de Colaboración Estado-Comunidades Autónomas suscritos durante 201329, los convenios de colaboración entre Administraciones Públicas pueden clasificarse teniendo en cuenta la finalidad y el contenido de los compromisos que las partes adquieren en el momento de su firma, y así pueden distinguirse:

a) Convenios que tienen por finalidad formalizar un mero intercambio de información o datos entre el Estado y las Comunidades Autónomas ${ }^{30}$.

b) Convenios que tienen por finalidad actuaciones de interés para la totalidad de las Comunidades Autónomas ${ }^{31}$.

c) Convenios de interés exclusivo para una Comunidad Autónoma ${ }^{32}$.

d) Convenios que formalizan el apoyo técnico de una Administración a otra con la finalidad de facilitar el ejercicio de sus competencias ${ }^{33}$.

e) Convenios que comportan la puesta en común de recursos de una u otra Administración ${ }^{34}$.

f) Convenios para la creación de entes comunes de gestión ${ }^{35}$.

g) Convenios para la organización de un evento en concreto $^{36}$.

${ }^{29}$ INFORME SOBRE LOS CONVENIOS DE COLABORACIÓN ESTADO-COMUNIDADES AUTÓNOMAS SUSCRITOS DURANTE 2013, cit., pág. 14 y ss.

30 Como, por ejemplo, los de intercambio de información sobre gestión de prestaciones sanitarias, realización de estadísticas e información agraria, pesquera y alimentaria, o para la elaboración de otras estadísticas y encuestas.

31 Por ejemplo, los de actuaciones en materia de desarrollo rural sostenible, los de financiación de programas especiales en niveles obligatorios de la enseñanza, los relativos al desarrollo de programas de incentivos de la actividad investigadora, o los que financian programas dirigidos a colectivos específicos, tales como mujeres víctimas de violencia de género, desempleados, inmigrantes, menores extranjeros no acompañados, etc.

32 Como los relativos a financiación de actuaciones en determinadas infraestructuras, como las actuaciones en cuencas hidrográficas, o de saneamiento y depuración de aguas.

33 Por ejemplo, los relativos a la cesión del uso de programas informáticos entre Administraciones, a la implantación de servicios digitales en educación y justicia, seguridad en edificios judiciales de la Comunidad Autónoma, o educación y sanidad en el ámbito penitenciario.

34 Como los que se refieren a la mejora y modernización de líneas ferroviarias o carreteras, los relativos a estadística e información sobre medio ambiente, agricultura, ganadería, silvicultura y pesca, los de ventanillas únicas empresariales, prestación mutua de servicios de Administración electrónica, o de cesión de datos con fines estadísticos.

35 Como puede ser un consorcio o una sociedad mercantil.

36 Como, por ejemplo, la creación del Consorcio Barcelona Mobile Word Capital, la celebración del XVI Congreso Internacional de Historia de los Conceptos en Bilbao, o la realización de la $15^{\mathrm{a}}$ edición del Master en Derecho marítimo y negocio marítimo y gestión portuaria Shipping Business en Barcelona. 
h) Convenios relativos a nuevos ámbitos de colaboración entre el Estado y las Comunidades Autónomas ${ }^{37}$.

No obstante, la crisis económica ha provocado que se limiten notoriamente los convenios que comporten nuevas obligaciones financieras, y los que conlleven cargas económicas importantes, como los relativos a grandes infraestructuras, que han quedado limitados a actuaciones prioritarias, mientras que, para actuaciones a medio plazo, se suelen firmar protocolos con la finalidad de estudiar la posibilidad de llevarlos a cabo en el futuro. A ello se añade que se han reajustado las anualidades previstas en muchos convenios, minorando las cuantías y las actividades a realizar u obras a ejecutar, o se ha extendido el plazo de ejecución de los convenios, alargando las anualidades para poder atender a su financiación con recursos futuros. Por el contrario, los convenios que no comportan contenido económico y los de colaboración sobre intercambio de datos o información, siguen suscribiéndose sin problemas para propiciar nuevos cauces de cooperación entre Administraciones Públicas.

\section{SUSCRIPCIÓN DE LOS CONVENIOS Y SUS EFECTOS}

\section{"Obra siempre de modo que tu conducta pudiera servir de principio a una legislación universal" Immanuel Kant}

Y mucho dista la nueva norma de parecerse a una legislación universal, o, cuanto menos, de esas que perduran a través de los siglos como algunos de nuestros ilustres códigos decimonónicos. No obstante, en materia de suscripción de convenios, ya la Disposición Adicional Decimotercera de la Ley 30/1992, recogía el régimen de suscripción de convenios de colaboración de la siguiente, aunque exigua, manera: "En el ámbito de la Administración General del Estado, los titulares de los Departamentos ministeriales y los Presidentes o Directores de los organismos públicos vinculados o dependientes, podrán celebrar los convenios previstos en el artículo 6, dentro de las facultades que les otorga la normativa presupuestaria y previo cumplimiento de los trámites establecidos, entre los que se incluirá necesariamente el informe del Ministerio o Ministerios afectados. El régimen de suscripción de los mismos y, en su caso, de su autorización, así como los aspectos procedimentales o formales relacionados con los mismos, se ajustará al procedimiento que reglamentariamente se establezca".

37 Como los convenios relativos a la conservación y restauración de la diversidad biológica en los espacios Red Natura 2000, la colaboración de los servicios de empleo con agencias de colocación privadas, o la colaboración para la protección de los trabajadores en contacto con el amianto. 
Ahora en la nueva norma ${ }^{38}$, como trámite preceptivo para la suscripción de los convenios, será necesario acompañarlos de una memoria justificativa donde se analice su necesidad y oportunidad, su impacto económico, el carácter no contractual de la actividad en cuestión, así como el cumplimiento de lo previsto en dicha Ley. Cuando se trate de convenios que suscriba la Administración General del Estado o sus organismos públicos y entidades de Derecho público vinculados o dependientes se acompañarán además de:

a) El informe de su servicio jurídico. No será necesario solicitar este informe cuando el convenio se ajuste a un modelo normalizado informado previamente por el servicio jurídico que corresponda.

b) Cualquier otro informe preceptivo que establezca la normativa aplicable.

c) La autorización previa del Ministerio de Hacienda y Administraciones Públicas para su firma, modificación, prórroga y resolución por mutuo acuerdo entre las partes.

d) Cuando los convenios plurianuales suscritos entre Administraciones Públicas incluyan aportaciones de fondos por parte del Estado para financiar actuaciones a ejecutar exclusivamente por parte de otra Administración Pública y el Estado asuma, en el ámbito de sus competencias, los compromisos frente a terceros, la aportación del Estado de anualidades futuras estará condicionada a la existencia de crédito en los correspondientes presupuestos ${ }^{39}$.

e) Los convenios interadministrativos suscritos con las Comunidades Autónomas, serán remitidos al Senado por el Ministerio de Hacienda y Administraciones Públicas.

Trámites de cuyo rigor en su cumplimiento práctico dependerá que esta figura vaya desprendiéndose de su fragilidad endémica, y vaya adquiriendo el vigor jurídico del que parece querer dotarla la Ley 40/2015.

${ }_{38}$ Se regula en el artículo 50 de la Ley 40/2015, de 1 de octubre, de Régimen Jurídico del Sector Público.

39 Señala DE DIEGO GÓMEZ, Alejandro, "La figura del convenio...", op. cit., pág. 2761, que es este un apartado difícil de entender ya que en los convenios plurianuales los compromisos asumidos por el Estado frente a terceros estarán condicionados por la existencia de crédito en presupuestos futuros, lo cual no parece lógico, ya que los compromisos de gasto frente a terceros documentados en un convenio deben de tener reflejo en los correspondientes presupuestos, y no al revés. A ello se une que el artículo 48.5 señala que "Los convenios que incluyan compromisos financieros deberán ser financieramente sostenibles, debiendo quienes los suscriban tener capacidad para financiar los asumidos durante la vigencia del convenio". Todo lo cual parece una pura contradicción que ya veremos cómo se solventa en la práctica. 


\section{EXTINGIÓN Y RESOLUGIÓN DE LOS CONVENIOS}

"Se mide la inteligencia del individuo por la cantidad de incertidumbres que es capaz de soportar'

Immanuel Kant

Y alguna que otra incertidumbre, que a continuación se analizará, aparece en la regulación de la extinción y resolución de los convenios conforme a la nueva Ley $40 / 2015^{40}$.

Los convenios se extinguen por el cumplimiento de las actuaciones que constituyen su objeto o por incurrir en causa de resolución.

Y son causas de resolución de los convenios:

a) El transcurso del plazo de vigencia del convenio sin haberse acordado la prórroga del mismo.

b) El acuerdo unánime de todos los firmantes.

c) El incumplimiento de las obligaciones y compromisos asumidos por parte de alguno de los firmantes.

En este caso, cualquiera de las partes podrá notificar a la parte incumplidora un requerimiento para que cumpla en un determinado plazo con las obligaciones o compromisos que se consideran incumplidos. Este requerimiento será comunicado al responsable del mecanismo de seguimiento, vigilancia y control de la ejecución del convenio y a las demás partes firmantes.

Parece ser pues que cualquiera de las partes que considere que la otra ha incumplido pudiera imponer un plazo determinado para que se produzca ese cumplimiento. No parece lógico que un agente privado exija a una Administración Pública, en un plazo por él impuesto, el cumplimiento de una obligación insatisfecha por ésta, lo lógico hubiera sido imponer un plazo concreto en las propias cláusulas convencionales. Incertidumbre pues añadida a los defectos ya constatados en esta regulación convencional.

Si trascurrido el plazo indicado en el requerimiento persistiera el incumplimiento, la parte que lo dirigió notificará a las partes firmantes la concurrencia de la causa de resolución y se entenderá resuelto el convenio. La resolución del convenio por esta causa podrá conllevar la indemnización de los perjuicios causados si así se hubiera previsto. 
d) Por decisión judicial declaratoria de la nulidad del convenio.

e) Por cualquier otra causa distinta de las anteriores prevista en el convenio o en otras leyes. Dándose la posibilidad de que las partes en el convenio establezcan otras causas distintas de resolución.

\section{EFEGTOS DE LA RESOLUGIÓN: LA LIQUIDAGIÓN DE LOS CONVENIOS}

\section{"La libertad es aquella facultad que aumenta la utilidad de todas las demás facultades" Immanuel Kant}

Y, siendo tan rentable la libertad en determinados contextos, no debe ser el de los convenios administrativos su ámbito más propicio, más bien al contrario, toda vez que en este estudio precisamente lo que se critica es la ausencia de regulación pormenorizada en determinados aspectos que evite la inseguridad jurídica y la utilización desnaturalizada del instrumento convencional. Por ello, la liquidación de los convenios no se produce libremente, sino únicamente cuando se produce el cumplimiento de los convenios o la resolución de los mismos. Como dice la norma, el cumplimiento y la resolución de los convenios dará lugar a la liquidación de los mismos con el objeto de determinar las obligaciones y compromisos de cada una de las partes ${ }^{41}$.

En el supuesto de convenios de los que deriven compromisos financieros, se entenderán cumplidos cuando su objeto se haya realizado en los términos y a satisfacción de ambas partes, de acuerdo con sus respectivas competencias, teniendo en cuenta las siguientes reglas:

a) Si de la liquidación resultara que el importe de las actuaciones ejecutadas por alguna de las partes fuera inferior a los fondos que la misma hubiera recibido del resto de partes del convenio para financiar dicha ejecución, aquella deberá reintegrar a estas el exceso que corresponda a cada una, en el plazo máximo de un mes desde que se hubiera aprobado la liquidación.

Transcurrido el plazo máximo de un mes, mencionado en el párrafo anterior, sin que se haya producido el reintegro, se deberá abonar a dichas partes, también en el plazo de un mes a contar desde ese momento, el interés de demora aplicable al citado reintegro, que será en todo caso el que resulte de las disposiciones de carácter general reguladoras del gasto público y de la actividad económico-financiera del sector público.

${ }^{41}$ Artículo 52 de la Ley 40/2015, de 1 de octubre, de Régimen Jurídico del Sector Público. 
b) Si fuera superior, el resto de partes del convenio, en el plazo de un mes desde la aprobación de la liquidación, deberá abonar a la parte de que se trate la diferencia que corresponda a cada una de ellas, con el límite máximo de las cantidades que cada una de ellas se hubiera comprometido a aportar en virtud del convenio. En ningún caso las partes del convenio tendrán derecho a exigir al resto cuantía alguna que supere los citados límites máximos.

No obstante lo anterior, si cuando concurra cualquiera de las causas de resolución del convenio existen actuaciones en curso de ejecución, las partes, a propuesta de la comisión de seguimiento, vigilancia y control del convenio o, en su defecto, del responsable del mecanismo de seguimiento, vigilancia y control de la ejecución del convenio y de los compromisos adquiridos por los firmantes, podrán acordar la continuación y finalización de las actuaciones en curso que consideren oportunas, estableciendo un plazo improrrogable para su finalización, transcurrido el cual deberá realizarse la liquidación de las mismas en los términos establecidos anteriormente.

Esta comisión de seguimiento, vigilancia y control del convenio, así como el responsable del mecanismo de seguimiento, vigilancia y control de la ejecución del convenio y de los compromisos adquiridos por los firmantes, no se determinan ni regulan en ninguno de los artículos del capítulo VI, por lo que no se sabe si queda a la libertad de las partes que convienen, o será únicamente la Administración quien decida los componentes de tal comisión y el responsable de tal "mecanismo" de seguimiento del convenio, mecanismo que, según el artículo 49.f) de la Ley 40/2015, se establecerá en cada convenio de manera independiente, como parte de su contenido, y resolverá los problemas de interpretación y cumplimiento que puedan plantearse respecto de los convenios. Es decir, que tanto la comisión de seguimiento como el mecanismo de seguimiento del convenio actuarán como una especie de controladores durante la vida del convenio y también para su liquidación, no entendiéndose tampoco por qué se establecen dos figuras claramente diferenciadas a este respecto, la comisión y el responsable del mecanismo, como si no tuviéramos ya empacho de comisiones los administrativistas.

\section{REMISIÓN DE LOS GONVENIOS AL TRIBUNAL DE GUENTAS}

"El Estado, al igual que el suelo sobre el que se halla situado, no es un patrimonio. Consiste en una sociedad de hombres sobre los cuales únicamente el Estado tiene derecho a mandar y disponer.

Es un tronco que tiene sus propias raíces"

Immanuel Kant

Y dado que el Tribunal de Cuentas de este Estado no estaba nada conforme con la regulación convencional que ahora se deroga, como puso de manifiesto claramente en su Moción 878, se establece en el artículo 53 de la Ley 40/2015, la obligación de 
remitírselos electrónicamente a él o al órgano externo de fiscalización de la Comunidad Autónoma, según corresponda, dentro de los tres meses siguientes a su suscripción, en el caso de convenios cuyos compromisos económicos asumidos superen los 600.000 euros.

Igualmente se comunicarán al Tribunal de Cuentas u órgano externo de fiscalización de la Comunidad Autónoma, según corresponda, las modificaciones, prórrogas o variaciones de plazos, alteración de los importes de los compromisos económicos asumidos y la extinción de los convenios indicados.

En definitiva, como recuerda JIMÉNEZ-BLANCO, se le da al Tribunal de Cuentas el estatuto propio de un buzón de correos $^{42}$, eso sí, de un flamante buzón de correos electrónico, como se merece un país 3.0 o $4 \mathrm{G}$.

Lo anteriormente señalado se entenderá sin perjuicio de las facultades del Tribunal de Cuentas o, en su caso, de los correspondientes órganos de fiscalización externos de las Comunidades Autónomas, para reclamar cuantos datos, documentos y antecedentes estime pertinentes con relación a los contratos de cualquier naturaleza y cuantía. Les queda pues el derecho a la pataleta, eso sí sólo respecto a "contratos". Y por qué dice la norma contratos cuando quiere decir convenios, sólo el legislador lo sabe..., aunque parece ser una errata evidente.

\section{ADAPTAGIÓN DE LOS GONVENIOS VIGENTES}

"La democracia constituye necesariamente un despotismo, por cuanto establece un poder ejecutivo contrario a la voluntad general. Siendo posible que todos decidan contra uno cuya opinión pueda diferir, la voluntad de todos no es por tanto la de todos, lo cual es contradictorio y opuesto a la libertad" Immanuel Kant

Pero como el poder legislativo, que en democracia emana de la soberanía popular, es el que hace las leyes, el legislador de la Ley 40/2015 ha establecido una Disposición Adicional Octava que contempla la obligación de adaptación a esta norma de todos los convenios vigentes suscritos por cualquier Administración Pública o cualquiera de sus organismos o entidades vinculados o dependientes en el plazo de tres años a contar desde la entrada en vigor de esta Ley, que se producirá el 2 de octubre de 2016, tras un año de vacatio legis.

${ }^{42}$ JIMÉNEZ-BLANCO CARRILLO DE ALBORNOZ, Antonio, "Organización administrativa...", op. cit., pág. 5 . 
No obstante, esta adaptación será automática, en lo que se refiere al plazo de vigencia del convenio, por aplicación directa de las reglas previstas en el artículo 49.h). $1^{\text {o43 }}$, para los convenios que no tuvieran determinado un plazo de vigencia o, existiendo, tuvieran establecida una prórroga tácita por tiempo indefinido en el momento de la entrada en vigor de esta Ley. En estos casos el plazo de vigencia del convenio será de cuatro años a contar desde la entrada en vigor de esta Ley. Pero no se especifica si es para la duración del convenio, para la prórroga también, o para ambas.

Por su parte, todos los organismos y entidades, vinculados o dependientes de cualquier Administración Pública y cualquiera que sea su naturaleza jurídica, existentes en el momento de la entrada en vigor de esta Ley deberán estar inscritos en el Inventario de Entidades del Sector Público Estatal, Autonómico y Local en el plazo de tres meses a contar desde dicha entrada en vigor.

\section{DISTINGIÓN ENTRE CONVENIOS, GONTRATOS Y SUBVEN- GIONES}

"El sabio puede cambiar de opinión. El necio, nunca". Immanuel Kant

Y no estaría de más que el legislador de la Ley 40/2015 cambiase de opinión en unos cuantos aspectos relativos a los convenios de cara a una futura reforma de una Ley que paradójicamente aún no ha entrado en vigor, y que nace ya con taras más propias de la vejez que de la más tierna infancia. No obstante, hay que reconocer que se ha esforzado levemente para procurar una distinción entre los convenios y otras figuras jurídicas con las que pudiera confundirse, y, de hecho, se confundía antes de esta norma, al no existir una definición legal de convenio. Aunque el esfuerzo es tan escaso que sólo se ha limitado a definir los convenios, pero sin aportar distinción conceptual alguna con los contratos y las subvenciones. Confusión con los contratos administrativos y con las subvenciones factible en la práctica, toda vez que puede ocurrir que, enmascarados bajo la forma de convenio, subyazcan una prestación y una contraprestación, o un beneficio exclusivamente para una de las partes.

Como decía el ilustre civilista español Federico DE CASTRO (1903-1983), los conceptos y las construcciones teóricas no tienen valor a priori y sólo se justifican por su utilidad, por lo que sería absolutamente estéril distinguir entre convenios, contratos y subvenciones si no se pretende encontrarle utilidad a esta distinción, cual es especi-

43 Que, recordemos, establece respecto al plazo de vigencia de los convenios que deberán tener una duración determinada, que no podrá ser superior a cuatro años, salvo que normativamente se prevea un plazo superior. 
ficar de la manera más precisa posible el régimen jurídico aplicable a cada una de las figuras mencionadas.

$\mathrm{Y}$ es que cuando un lector-operador jurídico se encuentra ante convenios, pactos, acuerdos bilaterales, contratos, etc., más que dejarse influenciar por la denominación de la figura que tiene delante, lo que tiene que hacer es preguntarse por la auténtica naturaleza del negocio jurídico que subyace tras un calificativo que apriorísticamente puede inducir a error. No en vano, la Sala de lo Contencioso-Administrativo del Tribunal Supremo tuvo que recordar en su Sentencia de 6 de febrero de 1989 que "Los convenios jurídicos son lo que legalmente son y no lo que semánticamente puedan significar".

No obstante, como señala MOREO MARROIG, "la diferencia entre contrato, convenio y subvención plantea un reto intelectual que no siempre da buenos frutos. En determinados asuntos ${ }^{44}$ la línea divisoria es tan fina que, algunas veces, se puede situar el negocio a un lado o al otro de la raya, sin vulnerar la legalidad" ${ }^{45}$. Y es que la falta de una definición jurídica respecto de los convenios ha favorecido que se haya utilizado esta figura para ejecutar gasto público sin en el encorsetamiento del Derecho Administrativo en materia de contratación pública y en materia de fomento, y, al calor de esta indefinición, han florecido tantas teorías, y criterios sobre los convenios como Administraciones, interventores y órganos de fiscalización externos tenemos en España ${ }^{46}$.

Por ello vamos a tratar de delimitar con la mayor precisión posible estas tres figuras, toda vez que la Ley 40/2015, al aportar una definición legal de convenio, ha venido a iluminar veladamente una zona oscura en la que hasta ahora ni doctrina, ni

44 Por ejemplo, en materia de servicios sociales.

45 MOREO MARROIG, Teresa, "De vuelta con la diferencia entre contrato, convenio y subvención", Observatorio de Contratación Pública, 10 de junio de 2013, pág. 1, que añade que "llama la atención que, últimamente, los fiscales, jueces y tribunales estén dando importancia a estos temas, incluso incorporando la doctrina que existe a sus resoluciones. El motivo se barrunta por su relación con las múltiples causas abiertas que existen en todo el territorio nacional, relacionadas con la corrupción, los delitos de prevaricación, malversación de fondos públicos, etc. Esta actitud de los órganos de la Justicia trae como consecuencia que los funcionarios responsables de la gestión de los fondos públicos, adopten una postura mucho más cautelosa a la hora de informar los expedientes de convenio, abandonando filosofías hasta hace poco comúnmente aceptadas", y analiza esta distinción a raíz del Auto de 17 de mayo de 2013 de la Audiencia Provincial de Palma de Mallorca (Sección Segunda) en el marco de la pieza separada número 25 (Noós) del caso Palma Arena, reflejando los hechos que presuntamente se utilizó la figura del convenio cuando debía haber sido un contrato y además, las actuaciones se llevaron a cabo por entidades no sujetas al control previo de legalidad. Para mayor abundamiento sobre la distinción entre contrato, convenio y subvención, vid., MOREO MARROIG, Teresa, "Los Convenios. Distinción entre las tres figuras jurídicas: subvención, contrato, convenio", Auditoría Pública, n 50, mayo de 2010.

46 HERVÁS SANZ, Alberto, "Convenios de Colaboración: Entre el mito y la realidad”, Red2Red Consultores, 26 de mayo de 2014, pág. 1 . 
jurisprudencia, ni legislador contemporizaban para aportar una construcción conceptual unitaria de convenio.

\section{Diferencias entre convenios y contratos}

La definición legal de convenio ya sabemos que se encuentra en el artículo 47.1 de la Ley 40/2015, recordémosla en este punto: "Son convenios los acuerdos con efectos jurídicos adoptados por las Administraciones Públicas, los organismos públicos y entidades de derecho público vinculados o dependientes o las Universidades públicas entre sí o con sujetos de derecho privado para un fin común".

Por su parte, la definición legal de contrato se encuentra en el artículo 2.1 del Real Decreto Legislativo 3/20011, de 14 de noviembre, por el que se aprueba el Texto Refundido de la Ley de Contratos del Sector Público: "Son contratos del sector público y, en consecuencia, están sometidos a la presente Ley en la forma y términos previstos en la misma, los contratos onerosos, cualquiera que sea su naturaleza jurídica, que celebren los entes, organismos y entidades enumerados en el artículo 3".

Pero recuerda taxativamente el artículo 47.1 in fine de la Ley 40/2015 que "Los convenios no podrán tener por objeto prestaciones propias de los contratos. En tal caso, su naturalezay régimen jurídico se ajustará a lo previsto en la legislación de contratos del sector público".

Y, en consonancia con ello, añade el artículo 4.1 del Texto Refundido de la Ley de Contratos del Sector Público que están excluidos del ámbito de dicha norma:

“c) Los convenios de colaboración que celebre la Administración General del Estado con las entidades gestoras y servicios comunes de la Seguridad Social, las Universidades Públicas, las Comunidades Autónomas, las Entidades locales, organismos autónomos y restantes entidades públicas, o los que celebren estos organismos y entidades entre sí, salvo que, por su naturaleza, tengan la consideración de contratos sujetos a esta Ley.

d) Los convenios que, con arreglo a las normas específicas que los regulan, celebre la Administración con personas fisicas o jurídicas sujetas al derecho privado, siempre que su objeto no esté comprendido en el de los contratos regulados en esta Ley o en normas administrativas especiales".

Convenios que se regirán, por tanto, por sus normas especiales, aplicándose exclusivamente los principios del Texto Refundido de la Ley de Contratos del Sector Público para resolver las dudas y lagunas que pudieran presentarse ${ }^{47}$.

47 Artículo 4.2 del Real Decreto Legislativo 3/20011, de 14 de noviembre, por el que se aprueba el Texto Refundido de la Ley de Contratos del Sector Público. 
No obstante, tanto convenios como contratos son negocios jurídicos bilaterales en Derecho Administrativo, por ello es importante que los convenios lo sean en la forma y en el fondo ${ }^{48}$, y no que, bajo la forma de convenio, en el fondo nos encontremos ante un contrato ${ }^{49}$. La diferencia esencial entre ambos estriba en que el convenio es un instrumento jurídico formalizado por escrito cuyo fundamento se encuentra en la necesidad de llegar a un acuerdo y plasma la concurrencia de voluntades entre dos o más partes -una de ellas una Administración Pública- adoptada en una posición de igualdad -cuanto menos teórica-, para colaborar en la consecución de un fin de interés común. Mientras que el contrato también es un instrumento jurídico formalizado por escrito, que plasmará un acuerdo en el que una parte se obliga al cumplimiento de una prestación a cambio de un precio cierto, y en el que la posición de supremacía de la Administración es muy relevante.

En los convenios no se manifiesta una contraposición de intereses, al contrario, se trata de establecer una colaboración institucional con la finalidad de llevar a cabo una actuación en respuesta de objetivos compartidos y ninguna de las partes tendrá interés patrimonial porque los intereses de las partes son públicos. Por el contrario, el contrato consiste en desarrollar una actividad singular y específica que forma parte del tráfico mercantil, existiendo total contraposición de intereses y un interés patrimonial ${ }^{50}$.

Cuando la Administración Pública actúa como promotor, el negocio es generalmente bilateral y, si además la materia objeto del negocio consiste en un contrato

48 Por ejemplo, un convenio que formalizan determinadas Comunidades Autónomas con el Tribunal Administrativo Central de Recursos Contractuales, en virtud del cual le atribuyen la competencia para resolver los recursos especiales en materia de contratación. Se trata de un convenio formalizado entre dos entes públicos, es un negocio oneroso y podría en parte identificarse con un contrato de servicios de los del artículo 10 del Texto Refundido de la Ley de Contratos del Sector Público, pero le faltan elementos para calificarlo de contrato porque su objeto no forma parte del tráfico mercantil, como apunta MOREO MARROIG, Teresa, "De vuelta con la diferencia...", op. cit., pág. 1. Estamos pues ante un convenio en la forma y en el fondo.

49 Por ejemplo, una Administración pretende utilizar la fórmula convencional para realizar un estudio, y conviene con otro sujeto, que es parte del convenio, por ejemplo, una Universidad, su realización a cambio de un precio. La actividad forma parte del tráfico mercantil, el objeto es perfectamente encuadrable en el concepto de contrato de servicios de los regulados en el artículo 10 del Texto Refundido de la Ley de Contratos del Sector Público y la posición que adoptan las partes que firman el convenio, desde el punto de vista económico consiste, por parte de la Universidad, en entregar el estudio encargado y, por parte de la Administración, abonar el precio pactado. Atendiendo a la naturaleza del negocio jurídico, puede concluirse que se trata de un contrato de los regulados en la legislación de contratos y, por tanto, resulta improcedente tramitarlo a margen de la normativa de contratos, como recuerda MOREO MARROIG, Teresa, "De vuelta con la diferencia...", op. cit., pág. 1. Bien es verdad que resulta extraña la figura del contrato entre Administraciones Públicas, pero no por ello puede quedar descartada. Estamos pues ante un instrumento cuya forma es de convenio, pero cuyo fondo es de contrato.

50 MOREO MARROIG, Teresa, "De vuelta con la diferencia...”, op. cit., pág. 1. 
regulado en el Texto Refundido de la Ley de Contratos del Sector Público o normas especiales, con independencia de la cuantía de la prestación y de la personificación pública o privada del sujeto que la debe realizar, el expediente se debe tramitar como un contrato y no como un convenio ${ }^{51}$.

\section{Diferencias entre convenios y subvenciones}

Frente a los negocios jurídicos bilaterales que acabamos de referir, en Derecho Administrativo existen también negocios jurídicos unilaterales, entre los que merece especial mención la subvención, en la que el promotor de la actividad es el agente receptor de fondos sin que exista contraprestación alguna para la Administración. Este negocio jurídico unilateral debe definirse como subvención y los expedientes al respecto se tramitarán con sujeción a la Ley 38/2003, de 17 de noviembre, General de Subvenciones.

En principio, parece pues que este negocio jurídico unilateral es incompatible con el convenio, en cuanto se trata de un negocio jurídico bilateral, no obstante, existen convenios instrumentales que formalizan subvenciones concedidas, tal y como prevé el artículo 48.7 de la Ley 40/2015, cuando dispone que "Cuando el convenio instrumente una subvención deberá cumplir con lo previsto en la Ley 38/2003, de 17 de noviembre, General de Subvenciones y en la normativa autonómica de desarrollo que, en su caso, resulte aplicable”. Asimismo, existen convenios necesarios para la gestión de las subvenciones previstas nominativamente en los Presupuestos Generales del Estado, de las Comunidades Autónomas o de las Entidades Locales, por lo que, se puede entender que, si bien el acto de concesión de la subvención es un acto unilateral, precisa para su plena eficacia la aceptación del beneficiario, otorgada en estos casos mediante la correspondiente suscripción del convenio instrumenta.

No obstante, en los convenios en los que existe interés patrimonial de una de las partes -como ya hemos analizado supra en el caso de los contratos onerosos-, o aquellos en los que está implícita una actividad de fomento -cuya formalización no suponga la instrumentalización de una subvención nominativa, permitida por el artículo 48.7 de la Ley 40/2015-, que presentan la forma de convenio, no lo son en la práctica, se trata de contratos o subvenciones encubiertas a los que se les debería aplicar a todos los efectos la normativa reguladora de estas figuras jurídicas, toda vez que "acudir a la figura del convenio como instrumento de ejecución del gasto público, ya sea su fin último una actividad de fomento o la compra de un bien o servicio, contraviene 
los principios de publicidad, transparencia, concurrencia, objetividad, igualdad y no discriminación" 52 .

\section{Diferencias entre contratos y subvenciones}

Entrando, a mayor abundamiento, en la diferenciación entre contrato y subvención, resulta evidente que la competencia administrativa para contratar está eminentemente relacionada con la actividad de servicio público o prestacional en sentido amplio, en la que el promotor es la Administración Pública, mientras que la subvención se enmarca en la esfera de la actividad de fomento, en la que la Administración procura la promoción o el estímulo incentivando la actividad de los particulares -o de otras Administraciones-, teniendo la consideración de promotor de la actividad incentivada el sujeto receptor de los fondos públicos. Como recuerda MORENO MARROIG, "Básicamente, estaremos ante una actividad de prestación cuando el objeto de la actuación de la Administración sea la prestación, no el fomento, de una actividad de titularidad pública y competencia del órgano que la realiza, bajo el régimen jurídico del Derecho público. En este caso aparecen dos sujetos activos. La Administración asume el papel de promotor. Por el contrario, estaremos ante una actividad de fomento cuando lo que se pretende con el negocio es proteger o estimular actividades que se consideran de interés público, pero que no son necesarias para el cumplimiento y realización de una competencia propia de ejecución de la Administración que actúa. La titularidad de la actividad no corresponde a la Administración que ejerce el fomento sino al sujeto que recibe los fondos que es el promotor. La Administración es el sujeto activo y el beneficiario el sujeto pasivo. La actividad financiada debe resultar de propiedad y utilización exclusiva del sujeto de Derecho privado que recibe la ayuda y, en el caso que el receptor sea otra Administración Pública, ésta debe ostentar competencias propias de ejecución sobre la materia subvencionada"53.

En definitiva, para diferenciar los convenios de los contratos y de las subvenciones, recordemos que el convenio comporta un acuerdo de voluntades en el que las partes firmantes tienen un objetivo compartido, de forma que ninguno de los interesados tiene interés patrimonial. El objeto del convenio no debe ser el pago de un precio cierto a cambio de una contraprestación, ni la concesión de una subvención pública a un tercero, cuyo objeto es el fomento de una actividad, y además las partes no deben tener interés patrimonial ni ánimo de lucro ${ }^{54}$.

52 HERVÁS SANZ, Alberto, “Convenios de Colaboración...”, op. cit., pág. 1.

53 MOREO MARROIG, Teresa, "De vuelta con la diferencia...”, op. cit., pág. 1.

54 HERVÁS SANZ, Alberto, “Convenios de Colaboración...”, op. cit., pág. 1. 


\section{CONGLUSIONES}

"Con las piedras que con duro intento los críticos te lanzan, bien puedes erigir tu monumento" Immanuel Kant

Aún a sabiendas de que mis críticas a esta novedosa regulación de los convenios pueden no ser compartidas por otros autores, me atrevo humildemente a realizarlas, en el entendimiento no sólo de que quizás pueda erigir mi propio monumento con sus críticas, sino también de que serán la propia experiencia práctica y la jurisprudencia quienes iluminen definitivamente este incompleto marco regulatorio.

Hay que reconocer el esfuerzo del legislador para otorgar seguridad jurídica a la utilización del instrumento convencional para propiciar no sólo el buen uso de esta figura jurídica, sino también una mayor transparencia en este tipo de relaciones de la Administración con los particulares, y desterrar la confusión entre convenios, contratos y subvenciones, aprovechada en muchas ocasiones para traspasar las delgadas líneas rojas existentes entre estas figuras jurídicas.

El convenio es una colaboración institucional firmada libremente para realizar una actuación en la que se comparten objetivos por ambas partes que convienen, no se trata pues ni de un contrato, en el que, a cambio de un precio se realiza una prestación tras un procedimiento de adjudicación, ni tampoco de una subvención, en la que la Administración transfiere fondos sin contraprestación alguna a un agente para financiar su actividad, pero puede intervenir tanto en la actividad de prestación como en la de fomento como presupuesto previo a la celebración de un contrato o al otorgamiento de una subvención.

Pero no puede perderse de vista que, precisamente por la libertad que ofrece la fórmula convencional en comparación con los rígidos procedimientos de adjudicación de los contratos, puede conducir al peligroso camino de que las Administraciones Públicas decidan utilizar los convenios para huir precisamente de la legislación contractual. Por eso, la juridificación de la figura del convenio en la Ley 40/2015 es un paso importante para evitar esta posible fuga, aunque se trate de una regulación manifiestamente mejorable.

No obstante lo anterior, si bien es cierto que la Ley 40/2015 convierte en derecho positivo la práctica administrativa de los convenios, sólo eleva a rango de ley parte de las recomendaciones que el Tribunal de Cuentas le hizo en su Moción 878. De las dieciséis propuestas que hizo el Tribunal de Cuentas para su consideración por las Cortes Generales y su traslado al Gobierno u otras instancias, el legislador únicamente ha hecho suyas algunas de aquellas recomendaciones, de la siguiente manera:

$1^{\circ}$.- Que se complete y sistematice el marco legal vigente respecto de los convenios de colaboración, formulando un concepto que los diferencie de figuras afines, 
precisando sus ámbitos subjetivo y objetivo y los extremos de su contenido. Recomendación atendida parcialmente, toda vez que, si bien se formula un concepto de convenio, en la Ley 40/2015 no se diferencia este concepto de los de contrato y subvención, para lo que hay que realizar las pertinentes operaciones de encaje jurídico entre esta norma, el Real Decreto Legislativo 3/2001 1, de 14 de noviembre, por el que se aprueba el Texto Refundido de la Ley de Contratos del Sector Público y la Ley 38/2003, de 17 de noviembre, General de Subvenciones.

$2^{\circ}$.- Que se precise el régimen aplicable a los convenios celebrados por entidades públicas que se rigen por el Derecho privado con otras entidades o Administraciones Públicas (el de los convenios interadministrativos o el de los convenios con administrados). Cuestión tampoco aclarada más allá de que en ambos casos se trata de convenios administrativos, sustanciándose las cuestiones litigiosas que de ellos se deriven en la jurisdicción contencioso-administrativa.

$3^{\circ}$.- Que se concrete si las relaciones entre Administraciones Públicas y organismos dependientes o vinculados deben canalizarse mediante convenios de colaboración o mediante encomiendas de gestión. Curiosamente en este punto ya se ha advertido que las encomiendas de gestión quedan fuera del ámbito de la regulación de los convenios por el artículo 48.9 de la Ley 40/2015, pasando a regularse en su artículo 11 .

$4^{\circ}$.- Que se adopten medidas eficaces para la efectiva aplicación de los principios de la legislación de contratos del sector público en los casos de ausencia de normas especiales. Sobre ello el artículo 47.2 in fine de la Ley 40/2015, lo único que aporta es que los convenios no podrán tener por objeto prestaciones propias de los contratos, y, en ese caso, su naturaleza y régimen jurídico se ajustarán a lo previsto en la legislación de contratos del sector público.

$5^{\circ}$.- Que en los convenios se delimiten con precisión el objeto y las actividades a realizar por las partes que convienen y la titularidad de los resultados. Cuestión sobre la que la Ley 40/2015 lo único que hace es recoger que la suscripción de convenios por las Administraciones Públicas en ningún caso podrá suponer cesión de la titularidad de la competencia.

$6^{\circ}$.- Que en los convenios en los que haya que realizar aportaciones financieras, se fije con rigor en su importe, que nunca deberá rebasar el coste de la actividad a financiar ni su valor de mercado. Recomendación plasmada en el artículo 48 de la Ley 40/2015, la crisis económica y la legislación sobre estabilidad presupuestaria y sostenibilidad financiera han cumplido su función.

$7^{\circ}$.- Que en las cláusulas de los convenios se incluyan las causas que pueden dar lugar a su modificación y resolución, así como las consecuencias del incumplimiento 
de sus compromisos. Recomendaciones asimismo satisfechas en los artículos 51 y 52 de la Ley $40 / 2015$.

$8^{\circ}$.- Que se definan y clarifiquen los criterios de imputación presupuestaria del gasto. En este como en el resto de asuntos relacionados con el gasto, el legislador ha prestado mucha atención a los aspectos financieros y económicos asociados a la suscripción de convenios.

$9^{\circ}$.- Que se evite la contracción de compromisos de ejercicios futuros con cargo a créditos con asignación nominativa, ni aún condicionándolos a la futura concesión de otro crédito nominativo. Recomendación cumplida en el artículo 50.2.d) de la Ley 40/2015, que señala que cuando los convenios plurianuales suscritos entre Administraciones Públicas incluyan aportaciones de fondos por parte del Estado para financiar actuaciones a ejecutar exclusivamente por parte de otra Administración Pública y el Estado asuma, en el ámbito de sus competencias, los compromisos frente a terceros, la aportación del Estado de anualidades futuras estará condicionada a la existencia de crédito en los correspondientes presupuestos, cuestión ya criticada supra.

$10^{\circ}$.- Que se evite la imputación automática de los saldos de compromisos no ejecutados del ejercicio anterior al presupuesto corriente sin una paralela modificación del plazo convenido. Tanto para esta recomendación como también para la $8^{\circ}$ y $9^{\circ}$, debemos reconducirnos a lo prevenido en el artículo 48.4 de la Ley 40/2015, que establece que la gestión, justificación y resto de actuaciones relacionadas con los gastos derivados de los convenios que incluyan compromisos financieros para la Administración Pública o cualquiera de sus organismos públicos o entidades de derecho público vinculados o dependientes que lo suscriban, así como con los fondos comprometidos en virtud de dichos convenios, se ajustarán a lo dispuesto en la legislación presupuestaria.

$11^{\circ}$.- Que se recabe la conformidad expresa de los suscriptores del convenio sobre las actuaciones a realizar cuando su concreción tenga que ser posterior a la suscripción del convenio. Sobre esta recomendación sólo aparece lo prevenido al inicio del artículo 48.8 de la Ley 40/2015, cuando recuerda que los convenios se perfeccionan por la prestación del consentimiento de las partes.

$12^{\circ}$.- Que se atribuya a una comisión de seguimiento o a un responsable del convenio las facultades de supervisión del mismo. Recomendación recogida en el artículo 49.f) de la Ley 40/2015.

$13^{\circ}$.- Que se justifique la ejecución del convenio mediante la comprobación material de las inversiones realizadas, tanto por el órgano gestor como por la intervención. Nada al respecto en la nueva norma más allá de las referencias genéricas a la legislación presupuestaria ya vistas. 
$14^{\circ}$.- En caso de que surjan dudas acerca de la delimitación de competencias entre el Estado y las Comunidades Autónomas, deberían de clarificarse en los convenios. Recomendación plasmada en el artículo 49.b) de la Ley 40/2015, en cuanto a la necesidad de que los convenios incluyan la competencia en la que se fundamenta la actuación de la Administración Pública, de los organismos públicos y las entidades de derecho público vinculados o dependientes de ella o de las Universidades públicas. En caso de conflicto, no se determina si entraría en acción el mecanismo de seguimiento, vigilancia y control de la ejecución del convenio del artículo 49.f).

$15^{\circ}$.- Que se complete y amplíe la información sobre los convenios mediante un sistema registral. La Disposición Adicional Séptima de la Ley 40/2015 crea un Registro Electrónico estatal de Órganos e Instrumentos de Cooperación ${ }^{55}$, al que se refiere expresamente el artículo 48.8 cuando señala que los convenios suscritos por la Administración General del Estado o alguno de sus organismos públicos o entidades de derecho público vinculados o dependientes resultarán eficaces una vez inscritos en el Registro Electrónico estatal de Órganos e Instrumentos de Cooperación del sector público estatal, al que se refiere la disposición adicional séptima y publicados en el «Boletín Oficial del Estado». Previamente y con carácter facultativo, se podrán publicar en el Boletín Oficial de la Comunidad Autónoma o de la provincia, que corresponda a la otra Administración firmante.

$16^{\circ}$.- Que se extienda a los convenios de colaboración la obligación de remitir información al Tribunal de Cuentas. Recomendación cumplida en el artículo 53 de la Lay 40/2015 para los convenios que superen los 600.000 euros, cuestión sobre la que se ha dado cumplida cuenta supra.

En fin, que el legislador ha hecho lo que ha considerado respecto a las recomendaciones del Tribunal de Cuentas, atendiéndolas en mayor o menos medida, o igno-

55 En los siguientes términos: "1. La Administración General del Estado mantendrá actualizado un registro electrónico de los órganos de cooperación en los que participa ella o alguno de sus organismos públicos o entidades vinculados o dependientes y de convenios celebrados con el resto de Administraciones Públicas. Este registro será dependiente de la Secretaría de Estado de Administraciones Públicas. 2. La creación, modificación o extinción de los órganos de cooperación, así como la suscripción, extinción, prórroga o modificación de cualquier convenio celebrado por la Administración General del Estado o alguno de sus organismos públicos o entidades vinculados o dependientes deberá ser comunicada por el órgano de ésta que lo haya suscrito, en el plazo de quince días desde que ocurra el hecho inscribible, al Registro Electrónico estatal de Órganos e Instrumentos de Cooperación. 3. Los Departamentos Ministeriales que ejerzan la Secretaría de los órganos de cooperación deberán comunicar al registro antes del 30 de enero de cada año los órganos de cooperación que hayan extinguido.4. El Ministro de Hacienda y Administraciones Públicas elevará anualmente al Consejo de Ministros un informe sobre la actividad de los órganos de cooperación existentes, así como sobre los convenios vigentes a partir de los datos y análisis proporcionados por el Registro Electrónico estatal de Órganos e Instrumentos de Cooperación. 5. Los órganos de cooperación y los convenios vigentes disponen del plazo de seis meses, a contar desde la entrada en vigor de la Ley, para solicitar su inscripción en este Registro. 6. Los órganos de cooperación que no se hayan reunido en un plazo de cinco años desde su creación o en un plazo de cinco años desde la entrada en vigor de esta ley quedarán extinguidos". 
rándolas, ha actuado dando la espalda a otras normas concomitantes o remitiendo a ellas desesperadamente según le convenía, o peor aún, aplicando la regla del mínimo esfuerzo, toda vez que ya ha supuesto un empeño titánico para él redactar ex novo los siete artículos del capítulo VI.

Junto a ello, es un hecho práctico que se ha reducido notablemente la planificación, vía convenio, de grandes obras de infraestructuras y programas de actuación que impliquen compromisos presupuestarios de largo alcance, unido al riguroso control en los proyectos de convenio con contenido económico, consecuencia de la exigencia del objetivo de estabilidad presupuestaria, y que ello ha incidido considerablemente en la reducción del número de convenios suscritos y también en los recursos asignados tanto por el Estadio como por las Comunidades Autónomas. Pero ello no implica que los convenios deban ser desterrados del acervo jurídico de las Administración española $a^{56}$ y menos aún ahora que gozan de una regulación propia, por muy incompleta y criticable que sea.

Que en los convenios debe primar el sentido colaborativo y no el interés patrimonial nadie lo duda, no obstante, a la luz de su nueva regulación, en cierta medida pudiera continuar siendo el instrumento frágil de antaño, rodeado de sutiles fronteras fáciles de traspasar. Por eso me quedo con las palabras de JIMÉNEZ-BLANCO en referencia al Proyecto de Ley de Régimen Jurídico del Sector Público que siguen teniendo igual trascendencia tras la publicación de la nueva norma. Señala que el texto se ocupa con profundidad de juridificar los convenios "todo un clásico en nuestro Estado de las Autonomías, sobre todo si se trata de levantar nuevas infraestructuras y hay que repartirse el coste", intentando "poner orden" en su regulación, aunque manteniendo una dificil posición intermedia entre los Protocolos Generales de actuación o instrumentos similares que comporten meras declaraciones de intención de contenido general o que expresen la voluntad de las Administraciones y partes suscriptoras de actuar con un objetivo común, y los contratos en sentido estricto ${ }^{57}$. Y apunta, en referencia genérica al Proyecto, que "el remedio legal está en la electrificación total, aun a riesgo de sufrir calambrazos, pero me temo que por sí solos Volta y Galvani no van a llevarnos al país 3.0 que necesitamos...", pensamiento plenamente extrapolable al instrumento convencional que aquí nos ocupa, cuya insuficiente regulación necesitaría quizás del impulso final de Tesla y su torre Wardenclyffe para dejar de ser un instrumento todavía lleno de incertidumbres y de perfiles sospechosos.

\footnotetext{
56 HERVÁS SANZ, Alberto, “Convenios de Colaboración...”, op. cit., pág. 1.

57 JIMÉNEZ-BLANCO CARRILLO DE ALBORNOZ, Antonio, "Organización administrativa...", op. cit., pág. 4.
} 


\section{BIBLIOGRAFÍA}

ALMEIDA CERREDA, Marcos, "Un ordenamiento con lagunas normativas: El caso de los convenios administrativos", Observatorio de Contratación Pública, 19 de diciembre de 2011.

DE DIEGO GÓMEZ, Alejandro, "La figura del convenio tras la Ley 40/2015, del Régimen Jurídico del Sector Público", El Consultor de los Ayuntamientos, no 23 , quincena del 15 al 29 de diciembre de 2015.

GONZÁLEZ-ANTÓN ÁLVAREZ, Carlos, Los convenios interadministrativos de los Entes Locales, Montecorvo, Madrid, 2002.

HERVÁS SANZ, Alberto, "Convenios de Colaboración: Entre el mito y la realidad", Red2Red Consultores, 26 de mayo de 2014.

INFORME SOBRE LOS CONVENIOS DE COLABORACIÓN ESTADO-COMUNIDADES AUTÓNOMAS SUSCRITOS DURANTE 2013, Ministerio de Hacienda y Administraciones Públicas, 2013.

JIMÉNEZ-BLANCO CARRILLO DE ALBORNOZ, Antonio, "Organización administrativa y relaciones interadministrativas", Documentación Administrativa, $\mathrm{n}^{\circ} 2$, enero-diciembre 2015.

KANT, Immanuel, Crítica de la razón pura, Riga, 1781.

KANT, Immanuel, Crítica de la razón práctica, Riga, 1788.

KANT, Immanuel, Crítica del juicio, Riga, 1790.

MARTÍN HUERTA, Pablo, Los convenios interadministrativos, Ministerio de Administraciones Públicas-INAP, 2000.

MOREO MARROIG, Teresa, "Los Convenios. Distinción entre las tres figuras jurídicas: subvención, contrato, convenio", Auditoría Pública, no 50, mayo de 2010.

MOREO MARROIG, Teresa, "De vuelta con la diferencia entre contrato, convenio y subvención”, Observatorio de Contratación Pública, 10 de junio de 2013.

MUÑOZ, M M Luisa y COYLE, Charles, "La nueva regulación de los convenios entre Administraciones Públicas y particulares", Actualidad Jurídica Aranzadi, no 914, 17 de diciembre de 2015.

RODRÍGUEZ DE SANTIAGO, José María, Los convenios entre Administraciones Públicas, Marcial Pons, Madrid, 1997.

TRIBUNAL DE CUENTAS, Moción 878/2010, de 30 de noviembre, del Tribunal de Cuentas a las Cortes Generales, sobre la necesidad de establecer un adecuado marco legal para el empleo del convenio de colaboración por las Administraciones Públicas, Boletín Oficial de las Cortes Generales número 480, de 28 de octubre de 2011.

VELASCO CABALLERO, Francisco, "Los convenios entre Administraciones Públicas", Revista Española de Derecho Administrativo, nº 103, 1999, págs. 504 a 511. 